\title{
Orality in the Gesta concilii Aquileiensis (AD 381)
}

\author{
Paola Francesca Moretti \\ Università degli Studi di Milano, \\ via Festa del Perdono 7, 20122, Milano, Italia; paola.moretti@unimi.it
}

For citation: Paola Francesca Moretti. Orality in the Gesta concilii Aquileiensis (AD 381). Philologia Classica 2019, 14(1), 107-120. https://doi.org/10.21638/11701/spbu20.2019.108

In this paper, a methodological issue is considered concerning the corpus of texts bearing witness to "spoken Latin". Within this corpus there are also some texts that have been neglected up until now, stemming from shorthand records of spoken utterances: all of them - either dialogal or monologal - share a conversational allure, that allows the singling out of both universal and historical features of spoken (late) Latin. One of these texts, the Gesta concilii Aquileiensis, is then examined: the shorthand report of a Church council summoned in AD 381, where a lively debate is recorded among bishops supporting opposite views - Catholic vs. Arian - of the divinity of Christ. The survey on the universal traits of orality surfacing in the Gesta focuses on the textual-pragmatic, the syntactic and the semantic levels. It leads to interesting results, concerning above all syntax (prominence of parataxis, and of descendent order of the phrasal constituents within the complex sentence, i.e. independent clause $>$ dependent clause) and semantics (lack of lexical innovation; inclination for expressive words). Despite the undeniably formal - and sometimes even formulaic - character of the dialogue, I would argue that the Gesta allow us to listen as it were to the voices of a group of cultured bishops animatedly discussing subtle theological matters.

Keywords: Latin language, spoken Latin, late Latin, Christian Latin, universal traits of orality, orality, Council of Aquileia (AD 381).

This paper aims at investigating the traces of orality surfacing in the Gesta concilii Aquileiensis. ${ }^{1}$ First, I will consider the methodological issue concerning the corpus witnessing the traits of 'spoken Latin'. I will argue that it also includes texts resulting from shorthand records of linguistic utterances performed viva voce, a category of texts that have so far been almost neglected. Second, I will focus on one of these texts, the Gesta concilii Aquileiensis, ${ }^{2}$ and attempt to single out the universal traits of orality featuring in it. The council of Aquileia took place on September $3^{\text {rd }}$, AD 381. It had been summoned by emperor Gratian, in order to have the bishops discuss the Trinitarian doctrines professed by Palladius of Ratiaria and Secundianus of Singidunum, two Illyrican bishops that were followers of Arius (who had been famously judged as a heretic at Nicaea, AD 325). Only Western bishops took part; among them, Ambrose of Milan was the most important

1 This paper was presented at the International conference 'Latin vulgaire - Latin tardif, XIII', in Budapest, Eötvös Loránd University, August 2019. I warmly thank all those who were present and discussed the paper, especially Tommaso Mari, who gave me some useful suggestions and later kindly sent me some of his own work.

${ }^{2}$ Latin text in Zelzer 1982, 325-368.

(C) St. Petersburg State University, 2019 
speaker on behalf of the Catholic party, that endorsed the Nicene creed. In the Gesta a lively debate is recorded, involving speakers who supported opposite views on the divinity of Christ.

\section{Shorthand records of 'spoken Latin'3}

Spoken utterances of any language can be recorded even through a written medium: as a matter of fact, this "unimportance of the medium" in the search for oral varieties of a language was the methodological premise of Johann Baptist Hofmann's investigation of 'Lateinische Umgangssprache.' ${ }^{4}$ Traces of orality can be preserved by any linguistic utterance as far as it reflects a 'langage de l'immédiat' (conceptional orality): ${ }^{5}$ so much so that in the case of 'Korpus-Sprachen' we can catch a glimpse of their totally lost spoken varieties from written documents bearing witness to a 'parlé graphique.'

Typologies of texts which are relevant thereof are listed by Wulf Österreicher: ${ }^{7}$ texts written by illiterate or semi-literate people (Pompeii graffiti, tabellae defixionum), sometimes in bilingual environments (letters by Claudius Terentianus and Rustius Barbarus, from Graeco-Roman Egypt); informal writing by educated people (Cicero's letters); writings accommodated to the (low) skills of the intended addressee (Latin translations of the Bible); literary texts mimicking orality (Plautus, Petronius, Apuleius). A further category is mentioned by Österreicher $(1998,151)$ : 'temoignages informels enregistrés... citations d'un langage informel, souvent grossier, que l'on a documenté, elsewhere referred to as 'passage au graphique d'un parlé spontané (procès verbaux, etc.)'. ${ }^{8}$ Österreicher doubtfully mentions a couple of examples: an adclamatio raised by the inhabitants of Rome against the Pope in 545 (recorded in the Liber Pontificalis) and the two exempla of genus adtenuatum that we read in Rhet. Her. 4, 62-66. To this category belong texts stemming from shorthand records of viva voce performances, ${ }^{9}$ which promise a 'close approximation to a verbatim record'10.

Furthermore, if we tone down the adjectives 'informel' and 'spontanée' featuring in Österreicher's definitions, we will be able to enlarge the corpus of texts conceivably hosting fragments of authentic orality. Basically, I suggest that these kind of texts might be arranged into two groups. ${ }^{11}$

(a) Some belong to 'dialogal discourse', in that they record dialogues, featuring the voices of more than one speaker: among them, the Gesta concilii Aquileiensis, to which I

3 This will also be discussed in a separate article.

4 Ricottilli $(2003,23$; 51) speaks of 'irrilevanza del medium. The first German edition of the seminal book by Hofmann (Italian translation in Hofmann 2003) was published in 1926 (Lateinische Umgangssprache, Heidelberg, Carl Winter).

5 Conceptional orality applies to texts in which the 'allure linguistique de lénoncé is conceived of as pertaining to a 'communication de l'immédiat', involving intimacy between the speakers, their co-presence in space and time, influence of emotion: Koch, Österreicher 2010, 584-588.

6 Koch, Österreicher 2010, 585.

7 Österreicher 1998, 149-153.

8 Koch, Österreicher 2010, 614.

9 Hagendahl 1971 is still fundamental for the investigation of the role played in Latin antiquity by shorthand reports of orally performed speeches of any kind; see also Teitler 1985.

10 Heath 2004, 263.

11 I draw on the terminology prompted by Karoline Kroon (Kroon 1995, 108-115); see also Moretti 2018, 4-6. 
shall return shortly; the Gesta collationis Carthaginiensis, a council featuring Augustine of Hippo and other Catholic bishops debating with their Donatist antagonists (AD 411); ${ }^{12}$ the Gesta senatus Romani de Theodosiano publicando, the recording of the session during which the Theodosian Code was presented to the senate in Rome (AD 438) $;^{13}$ verbatim reports of trials in the most ancient Acta martyrum. ${ }^{14}$

(b) Others belong to 'monologal discourse', as they are uttered by one speaker, who sometimes gives the floor to a - real or fictitious - interlocutor: he does so either overtly, so that the 'monologal' discourse becomes 'dialogical monologal', or in a more implicit and indirect way, so that the 'monologal' discourse, although spoken by one (that is 'monological'), takes on some conversational features, becoming 'diaphonic' ('diaphonic monological monologal'). Two examples of 'monologal' discourse, partly 'dialogical' and partly 'diaphonic monological' - it just depends on the sections we examine - are three works by Ambrose of Milan (Apologia David altera, Explanatio Symboli, De sacramentis), stemming from records of homilies preached by the bishop, ${ }^{15}$ and the Commentum in artem Donati of the African grammarian Pompeius, consisting of reports of his grammar classes. ${ }^{16}$

\section{The 'Gesta concilii Aquileiensis'}

At the beginning of September AD 381, a group of Western bishops came to Aquileia. Their gathering was formally presided over by the local bishop, Valerianus of Aquileia, but the discussion was actually lead by Ambrose of Milan. The purpose was to examine and to judge the doctrinal views of the two homaean - i.e. Arian - bishops Palladius and Secundianus, having them confronted with the core of Arius' doctrine: Christ would not share all God the Father's prerogatives, that is, his being eternal, good, wise, and true; rather, Christ, as 'son of God', would be inferior to God. After the first discussion, encompassing Palladius' trial, the bishop of Ratiaria was solemnly excommunicated by all the participants; then began Secundianus' trial, which is partially lost, as the Gesta break off abruptly. ${ }^{17}$

As McLynn puts it, 'the transcript of the [...] debate defies categorization': ${ }^{18}$ it appears a judicial trial, having Ambrose pursue decidedly his doctrinal allegations against the adversaries, who, besides defending their views, questioned the legitimacy of the council. ${ }^{19}$

The recording of that discussion, the proper Gesta, is preserved. In that they are an official report, the Gesta must be the result of an editing process similar to that which is

12 Ed. Weidmann 2018.

13 Regrettably, these Gesta are only an epitome of the words spoken and of the adclamationes uttered on that occasion: cf. Atzeri 2008, 118; 147-151; 161 (the Gesta are published at 319-322): however, this text remains fundamental as it likewise bears witness to a 'formal' and officially codified spoken Latin.

14 As suggested by De Ste. Croix 1984, 17-22 in a paper dealing with the Graeco-Roman world (at 23-24, he also hints at the recordings of Church councils).

15 See at least Visonà 2004, 61-65; 95; 132-133. The Explanatio Symboli will be dealt with in a separate article.

16 See Kaster 1988, 139-168; Pontani 2007, 207-210; Zago 2017, xcvii-xcix; Zago 2018.

17 McLynn 1994, 124-137.

18 McLynn 1994, 127.

19 Allegedly Gratian had summoned also the Eastern bishops, who were prevented from coming by Ambrose's maneuvers. On how, when, and by whom the bishops had been summoned to Aquileia, see Gryson $1980,121-132$. 
described in the Gesta collationis Carthaginiensis: ${ }^{20}$ shorthand record of the discussions (notae); transcription (descriptio) in apices evidentes; emendatio, followed by official approval (the speakers', the stenographers' and the judges' recognitio); publication (editio). As often mentioned by the speakers, also the Gesta concilii Aquileiensis are recorded by exceptores, chosen by both parties, their main task being to write down exactly each word as it was uttered:

(1) 34. Palladius dixit: "Tu iudex es, tui exceptores hic sunt". Ambrosius episcopus dixit: "Scribant tui qui volunt". 43. Palladius dixit: "Non tibi respondeo, quia quaecumque ego dixi non sunt scripta; vestra tantummodo scribuntur verba, non vobis respondeo". ... Palladius dixit: "Si vultis exceptores nostri veniant et sic totum excipiatur". Sabinus episcopus dixit: "Adducat suos exceptores". 46. Palladius dixit: "Exceptor vester et noster stent et omnia scribant". Valerianus episcopus dixit: "Iam quae dixisti et negasti scripta sunt omnia". 51. Palladius dixit: "Date auditores, veniant et ex utraque parte exceptores".

Shorthand reports of 'dialogal discourse' seemingly should give an insight into the ancients' spoken language. In this respect, two further clarifications are needed.

First, the accurate editing process, besides exposing the text to omissions and falsifications, certainly involved slight ameliorative formal changes, whose impact on the original linguistic facies of the text is difficult to guess: as a matter of fact, in the reworking of the original records most of the spontaneous marks of oral delivery are likely to have been expunged or amended, whereas only the original 'overall syntactic structure of the sentence' and 'lexicon' are likely to have been preserved. ${ }^{21}$

Second, the linguistic facies of the Gesta, from the very beginning of their oral performance, belong to a careful linguistic register, ${ }^{22}$ and must contain many technical and formulaic elements.

Despite that, I assume that neither revision nor presence of technical or formulaic turns of phrase prevent them from being almost exact recordings of high register spoken Latin, which reflect the actual wording of the participants, and are therefore worthy of linguistic investigation. ${ }^{23}$

As regards our text, its linguistic reliability is perhaps shown also by comparison with some passages of the Gesta which are quoted in the so called Scolia Maximini (= $S M$ ), a commentary put together by a certain Maximinus, ${ }^{24}$ and written on the margins surrounding the Gesta in the $5^{\text {th }}$ century manuscript Paris. Lat. 8907 (ff. 336r-353v: the commentary reads on ff. 336r-349r). As we will see below, in some cases the author of the

${ }^{20}$ Illustrated by Lancel 1972, 337-353, 390-391; Teitler 1985, 5-15; Atzeri 2008, 88-97. On the acta of Greek Church councils, see Graumann 2018 (dealing with Chalcedon).

${ }^{21}$ See the remarks by Mari, forthcoming, where even a comparison is made between the audio recording of a meeting of the UK House of Lords and its official shorthand report.

${ }^{22}$ On 'careful' and 'casual speech', see Adams 2013, 6. On the acta of bishops' councils as bearing witness to 'careful speech', see Moretti 2018, 8-10.

23 On the language of the Gesta conlationis Carthaginiensis, see Lancel 1972, 309-316 (oral traits), 321-327 (elements pertaining to the higher register, such as metrical and rhythmical clausulae); Pinkster 1998; Moretti 2018. For a comparable investigation of the Greek text of the Acta concilii Chalcedoniensis, see Mari, forthcoming.

24 Possibly, the Arian bishop who confronted Augustine in 427/428, a debate recorded in the Collatio cum Maximino Arianorum episcopo (cf. Gryson 1980, 63-79). See also Zelzer 1987, cliii (and n. 10), clvi-clvii, who dates Maximinus' writing from after AD 438. 
scolia quotes and comments upon a "better" text, that is not found in any of the surviving manuscripts of the Gesta. ${ }^{25}$ Obviously, it would be haphazard, although tempting, to speak of an 'Arian' version of the Gesta, also owing to the poor number of Maximinus' quotations; ${ }^{26}$ however, we might think that Maximinus, whilst commenting on the text, slightly amended it, even for the sake of clarity, deleting some oral elements.

In what follows, I will point out some universal oral traits which are found in the Gesta. ${ }^{27}$ Relevant passages of the text illustrating each phenomenon will be quoted, drawn from all the participants' speeches; the French and/or the Italian translations are added in square brackets, whenever they help elucidate the orality of the Latin text. ${ }^{28}$ Moreover, when statistical data are presented, they will result from the comparison between a sample of words spoken by bishop Ambrose during the council (971 words) ${ }^{29}$ and another text, which presumably bears witness to a formal register of 'written Latin': an official epistolary account of the council addressed to emperors Gratian, Valentinian, and Theodosius by Ambrose and the other bishops in September 381, which was circulated together with the Gesta (epist. 2: 976 words). ${ }^{30}$

\subsection{The textual-pragmatic level}

As for the universal traits of orality, the elements pertaining to the textual-pragmatic level are only scantily attested, perhaps because they do not usually escape an accurate revision: this is true, e.g., for discourse structuring particles (opening or closing or turn-taking markers).

A typical example is offered by et, which in oral passages may work as a turn-taking particle, rather than as a syntactic coordinating one: ${ }^{31}$

(2.a) 25. Palladius dixit: "Status divinus immortalis est". [a cunning answer, by means of which Palladius avoids asserting overtly Christ's immortality] Ambrosius episcopus dixit: "Astute et $[=$ etiam $]$ hoc, ut de dei filio nihil exprimas evidenter, et ego dico: Immortalitatem habet dei filius secundum divinitatem, aut nega quia habet immortalitatem".

(2.b) 39-40. Ambrosius episcopus dixit: "Subiectus secundum carnis rationem. Cetera et ipse meministi quia legisti: 'Nemo venit ad me nisi quem pater attraxerit”. Sabinus episcopus dixit: "Dicat si secundum divinitatem subiectus est patri an secundum incarnationem". Palladius dixit: "Ergo pater maior est". Ambrosius episcopus dixit: "Et alibi scriptum est: 'Fidelis deus per quem vocati estis in communionem fili eius"'.

(2.c) 69. Eusebius episcopus dixit: "Hoc Fotinus non negat, hoc Sabellius confitetur". Ambrosius episcopus dixit: "Et qui hoc non confitetur iure damnatur, ac per hoc saepe <te> convenio licet cavillando negaveris veritatem".

25 Gryson 1980, 54-58.

26 They preserve about $1 / 4$ of the surviving Gesta.

27 Cf. Koch, Österreicher 2010, 591-601. Koch 1998 examines the freedmen's speeches in Petronius as a sample of spoken Latin.

28 Both the Italian and the French translations I will refer to (Banterle 1988, 349-393; Gryson 1980, 330-383) rely on Zelzer's critical text and apparatus, which was shared with Gryson by the Austrian scholar before publication (cf. Gryson 1980, 57 n. 1).

${ }^{29}$ Chapters 1 to 32. Biblical quotations are ruled out.

30 Ed. Zelzer 1982, 316-325.

31 Koch 1998, 128-129. 
Also other particles, such as ergo (which furthermore looks like a linguistic tic in Ambrose's spontaneous speaking) ${ }^{32}$ and igitur, might be used as structuring devices. What is remarkable are the translators' hesitations between rewording and omitting them, which would not be easily accounted for if ergo/igitur had their most common logical conclusive meaning:

(3.a) 12. Ambrosius episcopus dixit: "... Dicitis quod Arrium <non> sequamini. Hodie aperta debet esse sententia: aut condemna illum aut astrue quibus vis lectionibus". Et adiecit: "Ergo iuxta epistulam Arri Christus dei filius non est sempiternus?

(3.b) 41. Ambrosius episcopus dixit: "Dicat quia non secundum divinitatem apostolus dixit subiectum sed secundum carnem; scriptum est enim: 'Humiliavit semetipsum factus obaudiens usque ad mortem'. In quo ergo mortem gustavit?" [Banterle omits ergo: 'In che cosa sperimentò la morte?'] Palladius dixit: "Qui<a> se humiliavit".

(4) 16. Felix episcopus et legatus dixit: "Si qui filium dei negaverit sempiternum et coaeternum negaverit, non solus ego legatus totius provinciae Africanae damno, sed et cunctus chorus sacerdotalis qui ad hunc coitum me sanctissimum misit etiam ipse ante damnavit". Anemius episcopus dixit: "Caput Illyrici non nisi civitas est Sirmiensis, ego igitur [Gryson omits igitur: 'et je suis'] episcopus illius civitatis sum. Eum qui non confitetur filium dei aeternum et coaeternum patri quod est sempiternum anathema dico, sed etiam is qui idem non confitetur".

Markers of correction, depending on insufficient discourse planning, are quite rare: ${ }^{33}$

(5) 50. Ambrosius episcopus dixit: "Damna impietatem Arri". Cumque reticeret Palladius, Eusebius episcopus dixit: "Superfluis immoramur. Tot impietates Arri Palladius noluit condemnare, immo potius asserendo confessus est. Hunc qui non damnat similis illius est et haereticus iure dicendus est".

As far as I could ascertain, modal particles, phatic contact markers, and interjections do not feature in our text.

\subsection{The syntactic level}

The syntactic level turns out to be quite interesting.

Admittedly, spoken language usually prefers parataxis and opts for independent clauses preceding dependent ones in hypotactic constructs ('ordine discendente', i.e. descendent order, as Durante puts it): this is accounted for in light of the ordering principle 'base, sviluppo, sviluppo...' which tends to shape oral syntactic structures. ${ }^{34}$

32 As shown by sacr. (Mohrmann 1976, 111, 114, 118) and expl. symb. (Moretti forthcoming). In the Gesta it occurs 16 times in Ambrose's spoken words. Another tic of Ambrose's idiolect is perhaps ac per hoc, to which I shall return below.

${ }^{33}$ Cf. Koch 1998, 131.

${ }^{34}$ Durante 1985, 54-55: 'Data una sequenza di enunciati, il primo convoglia una informazione che o è virtualmente autosufficiente, oppure configura una premessa che richiede continuazione. In entrambi i casi la funzione che compete al primo enunciato può essere definita col termine di base. L'enunciato successivo si aggancia al dato prioritario apportando nel primo caso una informazione aggiuntiva, e nel secondo caso integrando la linea semantica: chiamerò questa diversa funzione col termine di sviluppo. [...] Possiamo schematizzare questo semplicissimo principio organizzativo nella formula: base, sviluppo, sviluppo... [...] 
As regards the proportion between parataxis and hypotaxis, the impression one gets at a glance is that parataxis is prominent, independent clauses significantly outnumbering dependent ones. This is consistent with the 'statut problématique de l'hypotaxe' in spoken languages. ${ }^{35}$ The figures are quite meaningful, and the difference between Ambrose's spoken words and epist. 2 is apparent:

Table 1. Independent and dependent clauses

\begin{tabular}{|l|c|c|c|c|}
\hline & indep./dep. clauses & ratio indep./dep. clauses & $\max >\min$ length & average length \\
\hline Ambrose & $141 / 85$ & $1: 0.6$ & $58>1$ & 8.7 \\
\hline epist. 2 & $55 / 101$ & $1: 1.8$ & $73>4$ & 28.7 \\
\hline
\end{tabular}

In the words spoken by Ambrose the ratio independent/dependent clauses shows a clear prominence of the former over the latter, and clauses are often rather short: their average length is about 8.7 words. On the contrary, in the words written by the bishops the ratio independent/dependent clauses shows a prominence of dependent clauses, and clauses are often long: their average length is 28.7 words.

Sentence average length is no doubt a far-reaching feature. As a matter of fact, in the Gesta we find many examples of long sentences made up by coordinate clauses following one another per asyndeton, and of lively dialogue-strings, consisting of short clauses:

(6.a) 11. Ambrosius episcopus dixit: "Sequestrata sit causa orientalium, sententiam tuam hodie quaero. Arri tibi epistula lecta est; soles te Arrianum negare: aut damna hodie Arrium aut defende".

(6.b) 20. Ambrosius episcopus dixit: "Iohannes dixit in epistula sua: 'Hic est deus verus', nega hoc".

(6.c) 26. Ambrosius episcopus dixit: "Ergo male dixit Arrius, cum etiam filius dei habet immortalitatem secundum divinitatem". Et adiecit: "Bene dixit an male?" Palladius dixit: "Non consentio". Ambrosius episcopus dixit: "Cui non consentis? Anathema illi qui non explicat fidei libertatem". Omnes episcopi dixerunt: "Anathema". Palladius dixit: "Dicite quod vultis; eius est divinitas immortalis". Ambrosius episcopus dixit: "Cuius? Patris an et fili?" Et adiecit: "Multas impietates congessit Arrius, ad alia transeamus".

(6.d) 48. Palladius dixit: "Cum impietatis te argui, te iudice non utor, transgressor es". Sabinus episcopus dixit: "Quas impietates obicias fratri nostro et consacerdoti Ambrosio dicito". Palladius dixit: "Iam vobis dixi, pleno concilio respondeo et praesentibus auditoribus".

(6.e) 49-50. Valerianus episcopus dixit: "Nolite multum adigere Palladium, non potest vera nostra simpliciter confiteri; ipsius enim conscientia duplici blasfemia confusa est, nam a Fotinianis est ordinatus et cum ipsis est damnatus et nunc plenius damnabitur". Palladius dixit: "Hoc proba". Sabinus episcopus dixit: "Nec aliter poterat Christum verum <deum > negare nisi auctores suos sequeretur". Ambrosius episcopus dixit: "Obiecisti me esse impium, hoc proba". Palladius dixit: "Expositionem nostram afferimus, cum attulerimus, tunc disputatio habebitur". Ambrosius episcopus dixit: "Damna impietatem Arri".

Chiamerò questo tipo di articolazione sintattica col termine di ordine discendente. See also Koch, Österreicher 2010, 598 (drawing on Durante); Koch 1998, 135-137.

35 Koch 1998, 135. 
As for the order of sentences within the period, in the sample of spoken Latin we would expect the descendent order (independent clause $>$ dependent clause) to be prominent, according to the already mentioned principle of 'base, sviluppo, sviluppo.... However, the descendent order significantly prevails in both samples: it is found in 79 examples (out of 101 ) in the bishops' epistle (78.2\%), and in 60 examples (out of 85) in Ambrose's speeches $(70.5 \%)$. Furthermore, it should be remarked that anteposition of causal, temporal, conditional, and (in Latin) cum clauses, results in semantic (although not syntactic) descendent order, because time, condition, and cause work as semantic 'base', whose 'sviluppo' is the main clause, that is accordingly postposed. ${ }^{36}$ The prominence of descending order in both texts might be deemed to be typical of late Latin as a whole, as parallel to the trend from from left- to right-branching structures (SOV to SVO) involving word-order. ${ }^{37}$

Moreover, sometimes preposing of a dependent clause can be explained in pragmatic terms, as the topicalization of (phrasal) contrastive focus constituents, ${ }^{38}$ especially in highly conversational strings of text, that mirror the lively debate among the bishops:

(7.a) 23. Palladius dixit: "Et ego vos quod interrogavi respondere noluistis".

(7.b) 34. Palladius dixit: "Ego quae interrogo non respondetis?".

(7.c) 42. Palladius dixit: "Mandavi ut sederetis ut arguerem vos; quare subrepsistis imperatori? $\underline{U t}$ concilium plenum non esset, obrepsistis".

Topicalization might also involve noun contrastive focus constituents (8). It is definitely not by chance that words referring to the crucial issue which is debated - the definition of Christ as verus Deus - are topicalized:

(8.a) 17. Ambrosius episcopus dixit: "Et in hoc damna eum qui negat filium deum verum. Cum enim ipse sit veritas, quemadmodum non est deus verus?" Et adiecit: "Quid ad hoc?" Palladius dixit: "Filium verum qui non dicit?".

(8.b) 66. Ambrosius episcopus dixit: "Verum deum dicis?" Secundianus dixit: "Verum unigenitum filium qui negat verum filium dei?".

(8.c) 20. Cumque Palladius reticeret, Ambrosius episcopus dixit: "Solum verum filium dei qui dicit et non vult dicere deum verum, videtur negare".

(8.d) 28. Eusebius episcopus dixit: "Etiam Secundianus ad hoc respondeat". Cumque Secundianus reticeret, Ambrosius episcopus dixit: "Quia tacet, integrum vult habere iudicium". Et adiecit: "Solum patrem bonum cum dicit, filium confessus est an negavit?".

(8.e) 30. Ambrosius episcopus dixit: "Vides ergo quia Christum bonum filium, non bonum deum dicis, quod a te quaeritur". Et adiecit: "Bonum deum filium dei qui non confitetur, anathema".

Moreover, a remarkable merge of pragmatically determined orality and fixed formulas is found in the section containing the Catholic bishops' sententiae of condemnation (54-64). ${ }^{39}$ Iustus' sententia (9.a) shows the formulaic template as consisting of: Accusative of the direct object (topicalized focus) + relative clause, justifying the condemnation + damnandum censeo (and tantamount formulas). In Constantius' long sententia (9.b) the

36 Durante 1985, 55-56; Koch 1998, 137; Koch, Österreicher 2010, 598.

37 On Latin word order, see Bauer 2009; the parallel between syntactic micro- and macro-structures is underscored in Durante 1983, 63.

38 Gundel, Fretheim 2006. A similar phenomenon is examined in Pinkster 1998.

39 See also Pinkster 1998. 
direct object is preposed, and the accusative looks hanging until, in the end, the verb comes, governing it. In Amantius' sententia (9.c) we find left dislocation of the topicalized focus (Palladium), referred to by a co-referential pronoun (eum):

(9.a) 56. Iustus episcopus dixit: "Palladium, qui blasfemias Arri damnare noluit sed etiam has magis confiteri videtur, censeo ulterius sacerdotem dici non posse" ${ }^{\text {"40 }}$.

(9.b) 55. Constantius episcopus Arausicus dixit: "Palladium Arri discipulum, cuius impietates iam olim damnatae sunt a patribus nostris in concilio Nicaeno et nunc hodie probatae, cum recenserentur Palladio singulae - non confusus est dicere dei filium a deo patre esse alienum, cum creatura $<m>$ confitetur, cum temporalem dicit, deum verum negat -, in sempiternum censeo esse damnandum".

(9.c) 64. Amantius episcopus Lotevensium dixit: "Palladium qui sectam Arri non destruxit, secundum consacerdotum meorum $<$ sent $>e<n>$ tiam et ego eum condemno".

As can be easily seen, most of the sententiae result from the (more or less oral) reworking of a fixed formula.

In the Gesta there is almost no syntactic inconsistency. I could find only one - rather doubtful - example of interrupted sentence in (10):

(10) 11. [on the alleged role of the emperor in preventing the Eastern bishops from coming to Aquileia] Eusebius episcopus dixit: "Non credimus religiosum imperatorem aliud dixisse quam scripsit. Episcopos iussit convenire, non potuit tibi soli contra rescriptum suum dicere, ut sine orientalibus causa minime diceretur". Palladius dixit: "Si Itali soli iussi sunt convenire...". Evagrius presbyter et legatus dixit: "... Ut ante quattuor dies et ante biduum respondere $<s>$ $t<e>$ adfuturum. Quid ergo exspectabas? Ut dicis, orientalium consortium tuorum sententiam expectandam? Sic debuisti mandare, non promittere conflictum".

The Arians questioned the authority of the council, as Eastern bishops did not take part. The Catholic Eusebius reasserted the legitimacy of the assembly, notwithstanding the Eastern bishops' absence. I guess that Palladius' response (Si Itali soli iussi sunt convenire...) should be read as an interrupted sentence, sounding like: "But, what if only the Italians have been ordered to come.... It is interpreted as an interrogative clause in Zelzer's edition: but the omission of $s i$ in the two translations based on Zelzer's text betrays a difficulty (Gryson: 'Est-ce que seuls les Italiens ont reçu l'ordre de se réunir?'; Banterle: 'Solo gli Italiani hanno avuto lordine di riunirsi?'). Also Evagrius' response has not a straightforward interpretation (... Ut ante quattuor dies et ante biduum respondere $<s>$ $t<e>$ adfuturum): “... so that four days ago, and then two days ago, you answered you would be present". ${ }^{41}$ The passage as it is might reflect faithfully the fragmented allure of the dialogue, or must be otherwise corrupted. ${ }^{42}$ Again, Maximinus' text is less problematic (SM 22-23): $:^{43}$ should we think of him as drawing from a better manuscript or as willingly avoiding - i.e. amending - obscurities of the spoken text?

${ }^{40}$ Cf. all the other bishops' condemnation sententiae, which follow roughly the same scheme (54-64).

${ }^{41}$ Banterle 1988, 356-357 preserves Evagrius' answer as edited by Zelzer 1982, 332; whereas Gryson 1980, 357 amends it (partially based on Maximinus' text: see below, n. 43).

42 See the apparatus ad loc. in Zelzer 1982, 332.

43 Palladius dixit: “Ergo Itali soli iussi sunt convenire, exclusis eis?”. Evagrius presbyter et legatus dixit: "Et ante quattuor dies et ante biduum respondere te adfuturum dixeras. Ergo exspectabas, ut dicis, orien- 


\subsection{The semantic level}

Some further oral elements pertain to the semantic level, where the principles of economy and emotion play a crucial role.

As for economy, many passages reflect a trend to brachylogy. See for instance (11):

(11.a) 17. Ambrosius episcopus dixit: "Et in hoc damna eum qui negat filium deum verum. Cum enim ipse sit veritas, quemadmodum non est deus verus?" Et adiecit: "Quid ad hoc?" Palladius dixit: "Filium verum qui non dicit?". Ambrosius episcopus dixit: "Arrius negavit [scil. filium deum verum]".

(11.b) 25. Ambrosius episcopus dixit: "Astute et hoc [scil. dicis], ut de dei filio nihil exprimas evidenter, et ego dico: Immortalitatem habet dei filius secundum divinitatem, aut nega quia habet immortalitatem".

(11.c) 26. Palladius dixit: "Dicite quod vultis; eius est divinitas immortalis". Ambrosius episcopus dixit: "Cuius [scil. est divinitas immortalis]? Patris an et fili?".

(11.d) 32. Ambrosius episcopus dixit: "Filius dei deus potens est?" Palladius dixit: "Potens [scil. est]". Ambrosius episcopus dixit: "Deus bonus est?" Palladius dixit: "Iam dixi filium dei unigenitum esse potentem". Ambrosius episcopus dixit: "[scil. Dicis] Deum potentem". Palladius dixit: "[scil. Dico] Filium dei potentem".

A lack of lexical innovation is likewise remarkable. ${ }^{44}$ This feature can be quantified by calculating the 'Token/type ratio' index (= TTR), indicating the proportion between the total number of words and the number of different words (i.e. lexemes) featuring in a text. ${ }^{45}$ The TTR in epist. 2 is expectedly higher than in Ambrose's spoken words:

Table 2. The Token/type ratio

\begin{tabular}{|l|c|c|c|}
\hline & words & 'different' words & \%TTR \\
\hline Ambrose & 936 & 250 & 26.7 \\
\hline epist. 2 & 950 & 359 & 37.78 \\
\hline
\end{tabular}

But after all, it is remarkable that the TTR is not so high even in epist. 2. As a matter of fact, in both texts some technical or paramount words need to be repeated: e.g., in the Gesta we have dicere (= confiteri, "to assert according to the truth"), respondere ("to give an answer, defending oneself from an official charge"), or anathema (the curse formula). The Christian truth being at issue, both exactness and clearness are needed, which have an impact on lexical choice, as they might discourage from lexical variation. See for instance (12), where the emphasis is on deus, as this term embodies the divine prerogative that the Arians deny to Christ:

(12) 57. Eusebius episcopus Bononiensis dixit: "Quia impietates Arri diabolico stilo conscriptas, quas non licebat nec ad aures admittere, Palladius non solum noluit condemnare sed earum

talium consortium tuorum sententiam? Sic debuisti mandare, non promittere conflictum" (Gryson 1980, 222-223).

${ }^{44}$ Cf. Koch 1998, 138.

45 See also Mari forthcoming. Each lexical item counts for one "word" in absolute terms; each lexeme, together with all its flectional variants, counts for one "different word". Proper nouns, both personal and geographical, and all the biblical quotations have been ruled out. 
extitit assertor negando filium dei deum verum, deum bonum, deum sapientem, deum sempiternum, hunc a coetu sacerdotali et mea sententia et omnium catholicorum iudicio arbitror iure esse damnatum".

Among repetitions, I should perhaps single out two lexical 'tics', possibly typical of Ambrose's idiolect: ergo - sometimes working as a conclusive adverb, sometimes as a discourse marker ${ }^{46}$ - and ac per hoc ("and hence"), which in the Gesta appears only in Ambrose's spoken words, quite often and rather mechanically:

(13) 5. "Ecce quod Christianus constituit imperator: Noluit iniuriam facere sacerdotibus, ipsos interpretes constituit episcopos. Ac per hoc quoniam in sacerdotali concilio consedimus, responde ad ea quae tibi proponuntur. 21. "Etsi in multis impietatibus deprehensus sit, erubescimus tamen ut videatur qui sacerdotium sibi vindicat a laicis esse damnatus, ac per hoc quoniam et in hoc ipso damnandus est qui laicorum expectat sententiam cum magis de laicis sacerdotes debeant iudicare, iuxta ea quae hodie audivimus Palladium profitentem et iuxta ea quae condemnare noluit, pronuntio illum sacerdotio indignum et carendum ${ }^{47}$ ut in loco eius catholicus ordinetur. 68. "In hoc fraudem facis ut non deum verum dicas sed deum unigenitum, ac per hoc dic simpliciter: 'Unigenitus dei filius deus verus"'. 69. "Et qui hoc non confitetur iure damnatur, ac per hoc saepe <te> convenio licet cavillando negaveris veritatem; non quaero ut tantummodo unigenitum filium dei dicas sed etiam deum verum". 75. "Audi qua ratione permoveat nos et impietas et insipientia tua; cum dicis deum verum unigenitum, non deum verum dicis sed verum unigenitum, ac per hoc ut istam adimas quaestionem ita responde: Ex deo vero deus verus est".

Also the redundant presence of a second numquid in (14) might be explained as an oral repetition:

(14) 10. Palladius dixit: "Dixit mihi: 'Vade', diximus: 'Orientales conventi sunt?' Ait: 'Conventi sunt'. Numquid si orientales non fuissent conventi, numquid nos convenissemus?”.

The second numquid, which had been expunged from the text published in the editio Romana, ${ }^{48}$ should be preserved, as the redundancy is admissible in spoken language. It is noteworthy that numquid is omitted also in the SM $19 .{ }^{49}$

Besides economy, the second lexicon-informing trend is emotion, which accounts for the choice of some expressive words: ${ }^{50}$

(15.a) 15. Ambrosius episcopus dixit: "Dubitas [scil. Arrium] damnare post divina iudicia cum crepuerit medius?

(15.b) 59. Limenius episcopus Vercellensis dixit: "Arrianam doctrinam saepe esse damnatam manifestum est et ideo Palladius conventus in hac sancta synodo Aquileiensi quoniam noluit corrigere vel emendare $<$ se $>$ sed magis probavit deprehensibilem et oletavit [oletavit: editio Romana, Maurini, Gryson; olitavit: Zelzer, Banterle] perfidia quam se publice professus est tenere, habeat sententiam meam: et ego hunc profiteor a consortio sacerdotali esse privatum".

46 See above (3).

47 Perhaps to be emended into curandum?

48 Cf. apparatus ad loc. in Zelzer 1982, 332.

49 Numquid si orientales non fuissent conventi nos convenissemus? (Gryson 1980, 222).

50 See Koch 1998, 140. 
Medius crepuerit in (15.a) is a strong expression (Gryson: 'il a crevé par le milieu'; Banterle: 'egli è morto squarciato nel mezzo'), evoking Jude's death as referred to in the Acts of the Apostles. ${ }^{51}$

In (15.b) Palladius is said to have defiled (oleto, -are, linked to oleo, -êre "to stink") himself with heresy (Gryson: 'il a empesté l'hérésie'; Banterle: 'ha diffuso il fetore dell'empietà): oleto usually refers to physical contamination (of waters), and here is used metaphorically to describe spiritual defilement. ${ }^{52}$ I read oletavit (a lectio to be found in the editio Romana and in the Maurini, preferred also by Gryson) as olitavit, supported by the manuscripts, to be connected to an otherwise unattested olitio, -onis, "bad smell, stink". ${ }^{53}$ However, both variants have approximately the same meaning, and most importantly result in a lively metaphor.

Last but not least, very often suprasegmental features - voice intonation, etc. - must be added in order to fully understand the text, so that many sentences can only be understood when they are read aloud:

(16.a) 28. Palladius dixit: 'Legimus: 'Ego sum pastor bonus', et nos negamus? [of course we would not dare deny Christ's being bonus! Gryson: 'Nous lisons: Je suis le bon pasteur, et nous irions le nier?'; Banterle: 'Leggiamo: Io sono il buon pastore, e noi lo negheremo?'] Quis non dicat bonum dei filium?".

(16.b) 31. Item recitavit [scil. epistulam Arrii]: "Solum potentem". Ambrosius episcopus dixit: "Potens est filius dei an non?" Palladius dixit: "Qui omnia fecit non est potens, qui omnia fecit minus potest?!" [of course the one who made everything is powerful! how can you deny that?; Gryson: 'Celui qui a fait toutes choses n'est pas puissant? Celui qui a fait toutes choses ne puet pas grand-chose?'; Banterle: 'Chi ha fatto ogni cosa non è potente, chi ha fatto tutto ha minore potenza?'] Ambrosius episcopus dixit: "Ergo Arrius male dixit”. Et adiecit: "Vel in hoc damnas Arrium?" Palladius dixit: "Unde scio qui sit? Ego pro me respondeo tibi". Ambrosius episcopus dixit: "Filius dei deus potens est?" Palladius dixit: "Potens". Ambrosius episcopus dixit: "Deus bonus est?" Palladius dixit: "Iam dixi filium dei unigenitum esse potentem". Ambrosius episcopus dixit: "Deum potentem". Palladius dixit: "Filium dei potentem".

(16.c) 73. Ambrosius episcopus dixit: "A deo vero deus verus est". Secundianus dixit: "Et cum nomini etiam addis et 'verum', audis qualis in te fides sit, et Christianus es?" Eusebius episcopus dixit: "Qui negavit illum deum verum!? Arrius et Palladius negavit! [you dare ask: who denied it?! of course there are some who did deny it: Arrius and Palladius did!; Gryson: 'Qui a nié qu'il soit Dieu véritable? Arius et Palladius l'ont nié; Banterle: 'Chi ha negato che egli sia Dio vero? Lo hanno negato Ario e Palladio'] Tu si deum verum credis, debes simpliciter designare".

To reinforce the impression that this text reflects orality, perhaps it is worth noticing that even some historical features of spoken (late) Latin might be singled out, on which I will not dwell here: e.g., "quod/quia/quoniam-type clauses" replacing AcI as propositional

51 Act 1, 18: Et hic quidem possedit agrum de mercede iniquitatis et suspensus crepuit medius et diffusa sunt omnia viscera eius.

52 ThlL 9/2, 545, 23-29, s.v. oleto, -are. See Frontin. Aquaed. 97, 5-6: In isdem legibus adiectum est ita: "ne quis aquam oletato dolo malo, ubi publice saliet. Si quis oletarit, sestertiorum decem milium multa esto"; at 97, 7 a gloss has entered the text, which — although spurious — might be clarifying: [oletato videtur esse olidam facito].

53 ThlL 9/2, 563, 74-77, s.v. olitio, -ōnis. The word might be attested by Sen. Ep. 91, 21 (haec [scil. mors] malam olitionem habet), but Seneca's text is doubtful. 
objects or subjects; ${ }^{54}$ direct interrogative clauses with no interrogative particle; ${ }^{55}$ prominence of postposition of infinitive in Verb-Phrases 'auxiliary+infinitive', especially in main clauses, where word order is admittedly less conservative than in subordinate clauses. ${ }^{56}$

\section{Conclusion}

It is beyond doubt that we cannot assume that shorthand records straightforwardly reflect actual speeches, especially when we consider texts like the Gesta concilii Aquileiensis, whose language is formal and formulaic, and whose reports have undergone revision.

Nevertheless, the survey of universal traits of orality still surfacing in the Gesta might lead to interesting results. On the textual-pragmatic level, as can be expected, only a few discourse structuring particles have escaped revision, which work as markers of opening/closing/turn-taking, or correction. The syntactic level turns out to be perhaps more meaningful: prominence of parataxis, and of descendent order (independent clause $>$ dependent clause) in hypotactic constructs, together with pragmatics playing a crucial role. On the semantic level, I have remarked brachylogy, lack of lexical innovation (quantified in terms of TTR index), and sometimes an inclination for expressive words. Moreover, in some of the passages suprasegmental features must be added in order to fully understand the text.

To sum up, the Gesta enable us to have an insight into a formal register of spoken late Latin, and to allow the voices of the educated bishops gathered in Aquileia to decide the case of Palladius and Secundianus to surface in our imagination.

\section{References}

Adams J. N. Social Variation and the Latin Language. Cambridge, Cambridge UP, 2013.

Atzeri L. Gesta senatus Romani de Theodosiano publicando. Il Codice Teodosiano e la sua diffusione ufficiale in Occidente. Berlin, Duncker \& Humblot, 2008.

Banterle G. (ed.) Sant'Ambrogio, Lettere. Lettere fuori collezione. Avvenimenti del concilio di Aquileia. Milano - Roma, Biblioteca Ambrosiana - Città Nuova, 1988 (SAEMO 21).

Bauer, B. L. M. Word Order, in: Ph. Baldi, P. Cuzzolin (eds). New Perspectives on Historical Latin Syntax, I: Syntax of the Sentence. Berlin - New York, De Gruyter, 243-316.

Callebat L. (ed). Latin vulgaire - Latin tardif IV. Hildesheim - Zürich - New York, Olms, 1998.

De Ste. Croix G.E.M. A Worm's-Eye View of the Greeks and Romans and how they Spoke. Martyr-Acts, Fables and Other Texts. Latin Teaching 1984, 36.4, 16-30.

Durante M. Dal latino all'italiano moderno. Saggio di storia linguistica e culturale. Bologna, Zanichelli, 1985. Graumann T. Documents, Acts and Archival Habits in Early Christian Church Councils: a Case Study, in: A. Bausi, C. Brockmann, M. Friedrich, S. Kienitz (eds). Manuscripts and Archives. Comparative Views on Record-Keeping. Berlin - Boston, De Gruyter, 273-294.

Gryson R. (ed.) Scolies ariennes sur le Concile d’Aquilée. Paris, Cerf, 1980 (SCh 267).

${ }^{54}$ In Ambrose's words a rough equivalence between the two constructs is found (AcI: "quod-type" = 6:4, i.e. $40 \%$ of "quod-type" clauses), vs. a clear prominence of AcI in epist. 2 (AcI:"quod-type" = 16:1, i.e. $5.9 \%$ of "quod-type" clauses; quia occurs only once, to introduce a biblical quotation).

55 Such as: 12. "Ergo iuxta epistulam Arri Christus dei filius non est sempiternus?"; 14. "Verum deum dicis filium esse dei?"; 15. "Dubitas damnare post divina iudicia cum crepuerit medius?"; 18. "Verum deum dicis filium esse dei?"; 65. "Deum verum dei filium confiteris?"...

${ }^{56}$ In Ambrose's words, we find: Inf + Aux:Aux $+\operatorname{Inf}=1: 6$ (85.7 $\%$ of postposed Infinitive in main clauses), and Inf+Aux:Aux+Inf = 4:3 (subordinate clauses); in epist. 2: Inf+Aux:Aux+Inf = 5:6 (54.5\% of postposed Infinitive in main clauses), and Inf + Aux:Acc $+\operatorname{Inf}=9: 3$ (subordinate clauses). On this Verb-Phrase, see Moretti 2018, 3-12. 
Gundel J. K., Fretheim T. Topic and Focus, in: L. Horn, G. Ward (eds). The Handbook of Pragmatics. Malden MA - Oxford, Blackwell, 2006, 175-196.

Hagendahl H. Die Bedeutung der Stenographie für die spätlateinische christliche Literatur. JbAC 1971, 14, 24-38.

Heath M. Menander. A Rhetor in Context, Oxford, Oxford UP, 2004.

Hofmann J. B. La lingua d'uso latina. It. transl. by L. Ricottilli, Bologna, Pàtron, ${ }^{3} 2003$.

Kaster R. Guardians of Language: the Grammarian and Society in Late Antiquity, Berkeley, University of California Press, 1988.

Koch P.J. B., Österreicher W. Gesprochene Sprache und geschriebene Sprache - Langage parlé et langage écrit, in: Lexikon der romanistischen Linguistik I. 2: Methodologie. Tübingen, Niemeyer, ${ }^{2} 2010,584-627$.

Koch P. Une langue comme toutes les autres: latin vulgaire et traites universels de l'oral, in: Callebat 1998, 76-85.

Kroon C. Discourse Particles in Latin: a Study of 'nam', 'enim', 'autem', 'vero' and 'at'. Amsterdam, J. C. Gieben, 1995.

Lancel S. Actes de la conférence de Carthage en 411, I: Introduction général. Paris, Cerf, 1972 (SChr 194).

Mari T. Spoken Greek and the Work of Notaries in the Acts of the Council of Chalcedon [forthcoming].

McLynn N.B. Ambrose of Milan. Church and Court in a Christian Capital. Berkeley - Los Angeles Oxford, University of California Press, 1994.

Mohrmann C. Observations sur le De sacramentis et le De mysteriis de saint Ambroise, in: G. Lazzati (ed.) Ambrosius episcopus. Atti del Congresso internazionale di studi ambrosiani nel XVI centenario della elevazione di sant'Ambrogio alla cattedra episcopale. Milano, Vita e Pensiero, 1976, I: 103-123.

Moretti P. F. Is it Possible to Identify 'Orality'? Verb-Phrases 'Auxiliary+Infinitive' in Spoken (Late) Latin. Mnemosyne 2018, 71 (forthcoming, advance article: DOI: 10.1163/1568525X-12342462).

Österreicher W. Loral dans lécrit. Essai d'une typologie a partir des sources du latin vulgaire, in: Callebat 1998, 145-157.

Pinkster H. Word Order in the Late Latin Gesta conlationis Carthaginiensis, in: Callebat 1998, 549-560.

Pontani P. Ut puta si dicam. Grammatici latini e oralità. Aevum 2007, 81, 203-212.

Ricottilli L. Introduzione: Hofmann e il concetto di lingua d'uso, in: Hofmann 2003, 9-69.

Teitler H.C. Notarii and Exceptores: an Inquiry into Role and Significance of Shorthand Writers in the Imperial and Ecclesiastical Bureaucracy of the Roman Empire (from the Early Principate to c. 450 A.D.). Amsterdam, Gieben, 1985.

Visonà G. Cronologia ambrosiana. Bibliografia ambrosiana (1900-2000). Milano - Roma, Biblioteca Ambrosiana - Città Nuova, 2004 (SAEMO 25-26).

Weidmann C. (ed.) Collatio Carthaginensis anni 411: Gesta collationis Carthaginensis; Augustinus, Breviculus collationis; Augustinus, Ad Donatistas post collationem. Berlin - Boston, De Gruyter, 2018 (CSEL 104).

Zago A. (ed.) Pompeii commentum in artis Donati partem tertiam. Hildesheim, Weidmann, 2017.

Zago A. La mise en scène come espediente didattico nel Commentum artis Donati di Pompeo grammatico. Latinitas 2018, 6, 133-150.

Zelzer M. (ed.) Ambrosius, Epistularum liber decimus, Epistulae extra collectionem, Gesta Concili Aquileiensis. Vindobonae, Hoelder — Pichler - Tempsky, 1982 (CSEL 82/3).

Received: March 4, 2019

Accepted: April 22, 2019 